\title{
Frequency of hospitalization in patients diagnosed with congenital talipes equinovarus (CTEV)
}

\begin{abstract}
Introduction. Congenital talipes equinovarus (CTEV), also called clubfoot is the second after congenital dysplasia of the hip $(\mathrm{CDH})$ most frequently occurring congenital limb defect. In Europe the deformity affects 1-2 newborns in 1000 live births.

Aim. The aim of the study was to determine frequency of the deformity among other reasons for hospitalization, as well as depicting the profile of patients treated for clubfoot.

Material and methods. Study method was the analysis of medical documentation from two Orthopaedic Wards of Prof. Antoni Gębala Children's Hospital of Lublin. Medical records of patients treated for congenital talipes equinovarus (IDC 10-Q66.0) between 2008 and 2013 were the study material.

Results. Results of the study show that in the analyzed period of time 310 children were hospitalized for clubfoot in hospotal. $39.35 \%(n=122)$ of the total number of patients were girls and $60.65 \%(n=188)$ were boys. The average age of patients was 3.69 years, $(\mathrm{Me}=1.09$ years). Average age of girls was 4.17 ( $\mathrm{Me}=1.35$ years) and boys 3.89 (Me=0.83 years). The most numerous group consisted of infants up to 1 year ( $n=154 ; 49.68 \%)$.

Conclusions. Clubfoot affects boys twice as often as girls. Moreover, in the examined hospital the average length of stay for patients with clubfoot has decreased. The research reveals that the average hospitalization length in children with congenital talipes equinovarus is systematically decreasing. The study shows that the number of patients being admitted to the Children's Orthopedics Institute of the Hospital is increasing while the number of patients with clubfoot remains on the same level.
\end{abstract}

Keywords: congenital talipes equinovarus, clubfoot, lower limb defect, foot deformity.

DOI: $10.1515 /$ pjph-2015-0059

\section{INTRODUCTION}

Congenital talipes equinovarus (Lat. pes equino-varus congenitus) is the second most frequent lower limb defect. Defective morphological structure of the foot includes: adduction (turning under) of the forefoot and midfoot, adduction (varus), or turning in of the heel or hindfoot and fixed plantar flexion (equinus) of the ankle characterized by the drawn up position of the heel and inability to bring to foot to a plantigrade (flat) standing position impedes walking and standing [1-3]. Clubfoot (Figure 1) is a deformity affecting foot with function impairment and preserved anatomic structures and its main elements enumerated above are visible after birth [4-5].

Congenital talipes equinovarus has several clinical types. Orthopaedic doctor at the first examination has to assess not only the severity of the deformation but most importantly to what extent it is treatable in a passive manner. To do this, doctors use Dimeglio's four-point classification developed in the $90 \mathrm{~s}$, which is based on the degree to which it is correctable and on the deformity described by the appropriate order and composition of two words "soft" and "stiff".

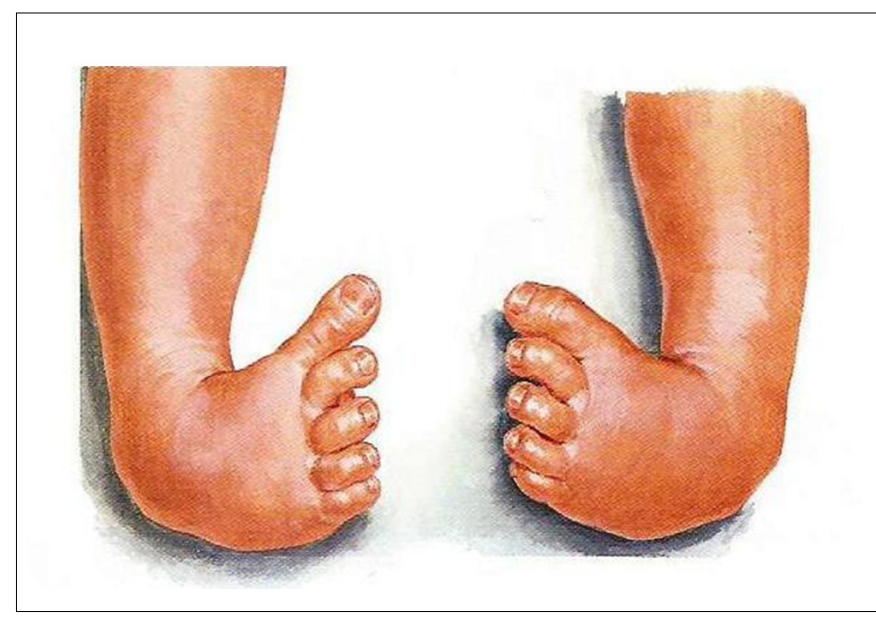

FIGURE 1. Bilateral congenital talipes equinovarus.

\footnotetext{
${ }^{1}$ Orthopaedic and Rehabilitation Supply Centre MUSI Lublin sp. z o.o., Poland

${ }^{2}$ Department of Emergency Medicine, Medical University of Lublin, Poland

${ }^{3}$ Children's Orthopaedic Clinic and Rehabilitation Department, Medical University of Lublin, Poland

${ }^{4}$ Chair and Department of Public Health, Medical University of Lublin, Poland
} 
Alan Dimeglio's foot deformity classification:

1. Type I soft-soft - soft foot, it is a positional deformity, easy to correct and position properly. It is benign foot deformity. It corresponds with habitual foot type and comprises $20 \%$ of all deformities.

2. Type II soft-stiff - soft-stiff foot undergoes positioning in the sagittal and horizontal plane to over 50 degrees, with tarsus varus below 20 degrees. Type II makes $33 \%$ of all deformities.

3. Type III stiff-soft - harder foot with deformity correction below 50 degrees in sagittal and horizontal plane, comprises $35 \%$ of all deformities.

4. Type IV stiff-stiff - hard foot, stiff, teratogenic with possible correction of equinus and adduction below 20 degrees with tarsus varus of above 45 degrees, makes $12 \%$ of all deformities [6-8].

\section{AIM}

The authors investigated the frequency to discover frequency of the deformity and elicited profiles of patients treated for clubfoot.

\section{MATERIAL AND METHODS}

The authors looked at an analysis of medical documentation of 310 patients treated for congenital talipes equinovarus (IDC 10-Q66.0), hospitalized in two Orthopedic Wards of Prof. Antoni Gębala Children's Hospital of Lublin between years 2008 and 2013. Patients were hospitalized in one of the two wards: Ward I- Children's Orthopedic and Rehabilitation Clinique of Medical University of Lublin's Orthopedic Department and Ward II- Children's Orthopedic Clinique of Medical University of Lublin. Children's Hospital in Lublin is the only place in the East macro region of Poland where patients with clubfoot are treated.

Data gathered in the study were analyzed with statistical methods. Values of the analyzed measurable parameters were represented by mean, median and standard deviation and nonmeasurable parameters were represented with the numerousness and percentage. In order to assess the normality of measureable parameters Saphiro-Wilk test W was employed.

Kruskal-Wallis analysis of multiple comparisons was used to compare many independent groups. Chi square distribution test was used to determine differences between frequencies in compared groups with qualitative values.

Significance level of $\mathrm{p}<0.05$ was employed to indicate the existence of statistically significant differences. Data base was created and statistical analysis was conducted with STATISTICA 10.0 software (StatSoft, Poland).

\section{RESULTS}

A statistical analysis of the documentation gathered at Medical University of Lublin Children's Orthopedic Department between years 2008-2013 showed that 310 children were hospitalized for congenital talipes equinovarus, $39.35 \%$ of which were girls $(n=122)$ and $60.65 \%$ were boys $(n=188)$. Average age of the group was 3.69 years $(\mathrm{Me}=1.09$ years). Average age of girls was $4.17(\mathrm{Me}=1.35$ years) and boys $3.89(\mathrm{Me}=0.83$ years). The most numerous age group were infants up to one year $(n=154 ; 49.68 \%)$, while $21.29 \%(n=66)$ of patients were aged 1 to $3,16.13 \%(n=50)$ aged 4 to 10 and $12.90 \%(n=40)$ were more than 10 years old. $62.23 \%(n=196)$ of the analyzed group was hospitalized between years 2008 and 2013 in I Children's Orthopedic Ward and 36.77\% $(n=114)$ in II Children's Orthopedic Ward. Among patients treated for congenital talipes equinovarus $89.35 \%(n=277)$ were treated for the deformity as a main illness, clubfoot in $0.97 \%(\mathrm{n}=3)$ patients was an additional illness while $9.68 \%(n=30)$ had clubfoot as an concurrent illness. Admission frequency analysis shows that clubfoot patients were more frequently admitted in $2010(\mathrm{n}=72)$ and 2011 ( $n=62)$, than in $2008(n=44)$, when the least numerous group of patients diagnosed with CTEV was admitted (Table 1).

TABLE 1. Frequency of clubfoot between 2008-2013 in relation to the total number of patients admitted in Children's Orthopedic Department of Medical University of Lublin.

\begin{tabular}{|c|c|c|c|c|c|c|}
\hline \multirow{3}{*}{ Year } & \multicolumn{4}{|c|}{ All admissions } & \multirow{2}{*}{\multicolumn{2}{|c|}{ Total }} \\
\hline & \multicolumn{2}{|c|}{ Clubfoot diagnosis } & \multicolumn{2}{|c|}{ Other reason } & & \\
\hline & $\mathbf{n}$ & $\%$ & $\mathbf{n}$ & $\%$ & $\mathbf{n}$ & $\%$ \\
\hline 2008 & 44 & $2.51 \%$ & 1710 & $97.49 \%$ & 1754 & $100.00 \%$ \\
\hline 2009 & 45 & $2.32 \%$ & 1894 & $97.68 \%$ & 1939 & $100.00 \%$ \\
\hline 2010 & 72 & $3.42 \%$ & 2032 & $96.58 \%$ & 2104 & $100.00 \%$ \\
\hline 2011 & 62 & $2.20 \%$ & 2756 & $97.80 \%$ & 2818 & $100.00 \%$ \\
\hline 2012 & 51 & $1.75 \%$ & 2870 & $98.25 \%$ & 2921 & $100.00 \%$ \\
\hline 2013 & 49 & $1.51 \%$ & 3203 & $98.49 \%$ & 3252 & $100.00 \%$ \\
\hline
\end{tabular}

Source: Netter F. Netter's Orthopaedic Anatomy Atlas. 2007, p. 259

Medical University's Children's Orthopedic Department material was analyzed in the study. The examined department consists of two clinics: Children's Orthopedic and Rehabilitation Clinic of Children's Orthopedic Department referred to as "Ward I" and Children's Orthopedic Clinic referred to as "Ward II" in the organizational structure of Children's Hospital of Lublin. Study reveals that the majority of patients with congenital talipes equinovarus $(63.23 \%)$ were hospitalized in Ward I and $36.77 \%$ of patients were hospitalized in Ward II within the examined period. In Ward I the total number of patients with clubfoot equaled 209 while the general number of all patients summed up to 7243. In the examined years the percentage of patients with CTEV in relation to total number of admissions equaled $2.88 \%$. Over the examined years the percentage changed as follows: in $2008-2.9 \%, 2009-3.05 \%$, $2010-4.62 \%, 2011-3.13 \%, 2012-2.08 \%$ while in year 2013 the percentage dropped to $1.90 \%$. The number of patients treated for clubfoot in later years was similar to the number form first years of the examined period and systematic decline in the percentage is caused by the increase in the total number of patients treated in the hospital. In the Ward II during the examined period 114 patients with clubfoot were hospitalized while the total number of patients amounted to 7336. Some $1.55 \%$ of the total number of patients hospitalized in the Ward II, were patients diagnosed with congenital talipes equinovarus. Over the years, the percentage of clubfoot patients was dropping systematically: $2008-2.02 \%, 2009-1.57 \%, 2010$ $-2.25 \%, 2011-1.46 \%, 2012-1.35 \%$ to reach $1.11 \%$ in 2013 . Results of the analysis indicate that among children treated for clubfoot in 2013 , boys $(63.27 \%)$ were significantly more frequently hospitalized than girls (36.73\%).

A similar discrepancy was observed is observed in year 2008 (74.19\% of boys compared to $25.81 \%$ of girls) and in 
year 2009 (71.11\% and $28.89 \%)$. In the remaining years the frequency of admission was equal - similar number of boys and girls was admitted. Differences are not statistically significant $(\mathrm{p}=0.14)$.

TABLE 2. Number of patients treated for congenital talipes equinovarus in Children's Orthopedic Department of Medical University of Lublin in years 2008-2013 according to gender.

\begin{tabular}{|c|c|c|c|c|c|c|}
\hline \multirow{3}{*}{ Year } & \multicolumn{4}{|c|}{ Gender } & \multirow{2}{*}{\multicolumn{2}{|c|}{ Total }} \\
\hline & \multicolumn{2}{|c|}{ Girls } & \multicolumn{2}{|c|}{ Boys } & & \\
\hline & $\mathbf{n}$ & $\%$ & $\mathbf{n}$ & $\%$ & $\mathbf{n}$ & $\%$ \\
\hline 2008 & 11 & $25.00 \%$ & 33 & $75.00 \%$ & 44 & $100.00 \%$ \\
\hline 2009 & 13 & $28.89 \%$ & 32 & $71.11 \%$ & 45 & $100.00 \%$ \\
\hline 2010 & 36 & $50.00 \%$ & 36 & $50.00 \%$ & 72 & $100.00 \%$ \\
\hline 2011 & 26 & $41.94 \%$ & 36 & $58.06 \%$ & 62 & $100.00 \%$ \\
\hline 2012 & 21 & $41.18 \%$ & 30 & $58.82 \%$ & 51 & $100.00 \%$ \\
\hline 2013 & 18 & $36.73 \%$ & 31 & $63.27 \%$ & 49 & $100.00 \%$ \\
\hline \multicolumn{7}{|c|}{ Statistical analysis $\mathrm{Chi}^{2}=8.25 ; \mathrm{p}=0.14$} \\
\hline
\end{tabular}

$\mathrm{n}=323,11$ children were hospitalized several times

Taking into consideration patients' age on the day of admission, statistical analysis did not show any significant differences among examined years $(\mathrm{p}=0.60)$. Each age group has the same frequency of admission in the analyzed years. However, the most numerous group of patients treated for congenital talipes equinovarus comprised of infants up to one year old.

TABLE 3. Frequency of congenital talipes equinovarus in Children's Orthopaedic Department of Medical University of Lublin in years 20082013 according to the age on the day of admission.

\begin{tabular}{|c|c|c|c|c|c|c|c|c|c|c|}
\hline \multirow{3}{*}{ Year } & \multicolumn{8}{|c|}{ Age } & \multirow{2}{*}{\multicolumn{2}{|c|}{ Total }} \\
\hline & \multicolumn{2}{|r|}{$\begin{array}{l}\text { Up to } \\
1 \text { year }\end{array}$} & \multicolumn{2}{|c|}{ 1-3 years } & \multicolumn{2}{|c|}{ 4-10 years } & \multicolumn{2}{|c|}{$\begin{array}{c}\text { More than } \\
10 \text { years } \\
\end{array}$} & & \\
\hline & $\mathbf{n}$ & $\%$ & $\mathbf{n}$ & $\%$ & n & $\%$ & $\mathbf{n}$ & $\%$ & $\mathbf{n}$ & $\%$ \\
\hline 2008 & 20 & $45.46 \%$ & 13 & $29.55 \%$ & 5 & $11.36 \%$ & 6 & $13.63 \%$ & 44 & $100.00 \%$ \\
\hline 2009 & 22 & $48.89 \%$ & 10 & $22.22 \%$ & 7 & $15.56 \%$ & 6 & $13.33 \%$ & 45 & $100.00 \%$ \\
\hline 2010 & 42 & $58.33 \%$ & 11 & $15.28 \%$ & 9 & $12.50 \%$ & 10 & $13.89 \%$ & 72 & $100.00 \%$ \\
\hline 2011 & 29 & $46.77 \%$ & 15 & $24.19 \%$ & 10 & $16.14 \%$ & 8 & $12.90 \%$ & 62 & $100.00 \%$ \\
\hline 2012 & 27 & $52.94 \%$ & 12 & $23.53 \%$ & 6 & $11.77 \%$ & 6 & $11.76 \%$ & 51 & $100.00 \%$ \\
\hline 2013 & 22 & $44.90 \%$ & 9 & $18.37 \%$ & 14 & $28.57 \%$ & 4 & $8.16 \%$ & 49 & $100.00 \%$ \\
\hline & & & atst & cal analis & ys. & $C h i^{2}=13$ & & $=0.60$ & & \\
\hline
\end{tabular}

$\mathrm{n}=323,11$ children were hospitalized several times

Table 4 presents the hospitalization time of clubfoot patients in years 2008-2013 in Children's Orthopedic Department of Medical University of Lublin. Conducted analysis revealed that among particular years the hospitalization time was significantly different $(\mathrm{p}=0.0002)$. Multiple comparison analysis showed that hospitalization time in years 2008, 2009 significantly differed in comparison to years 2010, 2011, 2012 and 2013, while among the remaining years the differences were not statistically significant $(\mathrm{p}>0.05)$.

\section{DISCUSSION}

Congenital talipes equinovarus is the second most frequent limb defect and affects around 135000 newborns worldwide. In Europe clubfoot affects 1-2 newborns per 1000 live births. In China cases of the deformity are the least frequent where in 1000 births only 0.3 children are affected with CTAV [9-19]. In Hawaii and Tonga in turn, 6-7 infants in 1000 births are reported to be born with clubfoot [20]. Maori Islands' medical records also show high percentage of clubfoot patients (6-7 cases in 1000 births) [21]. High number of children with CTAV is also observed in New Zealand where 6.8 infants in 1000 births are born with the deformity [22].

Boys suffer from clubfoot twice as often as girls, although in girls the deformity is more severe and less likely to be cured. Reason for this sexual dimorphism where men are two times more frequently affected by the deformity are still unknown $[6,23,24]$. Presented research confirms the thesis about higher probability of diagnosing clubfoot in male infants than in females. In the researched group $39.35 \%(n=122)$ of patients were girls while $60.65 \%(n=188)$ were boys.

Ostrowski's analysis of clubfoot hospitalization in years 1970-1999 showed that $68 \%$ of the total number of 1041 children hospitalized were boys while $32 \%$ were girls [25]. Etiology of clubfoot is researched by many scholars, yet main reasons of the deformity are still unknown [26-29].

Researchers of congenital talipes equinovarus give few factors as causes of the deformity. Probable causes include: environmental exposure to tobacco, genetic disorders, tobacco exposure combined with hereditary factors or even seasonal virus infections [30-34]. Other premises suggest that primary causes of clubfoot are osseous system modifications or soft tissue alteration. Differences in the clinical picture of clubfoot may indicate differences in its etiology. Benign clinical types can be connected with mechanical causes of external origin, like incorrect position of a child's foot in uterus or small amount of amniotic fluids. Some authors claim that clubfoot is not an embryonic deformity as the affected foot at first develops correctly to become equinovarus in the second trimester. CTAV is a developmental deformity [35]. It can exist as one of the components in one syndrome or as an isolated defect. Considering the deformity as a syndrome, clubfoot origins as well as its inheritance correspond with its etiology. When the defect is isolated the etiology is not known. Inheritance of CTAV can be estimated on the level of $24 \%$. In multifactor etiology the risk of clubfoot inheritance decreases to only $3 \%[9,36,37]$. In case of the multifactor inheritance when only one boy in a family has clubfoot the risk of its occurrence in the next

TABLE 4. Hospitalization time in years between 2008 and 2013 in Children's Orthopedic Department of Medical University of Lublin .

\begin{tabular}{lccccc}
\hline \hline Year & Mean & $\begin{array}{c}\text { Standar } \\
\text { dev. }\end{array}$ & $\begin{array}{c}\text { Lower } \\
\text { quartile }\end{array}$ & Median & $\begin{array}{c}\text { Upper } \\
\text { quartile }\end{array}$ \\
\hline 2008 & 5.56 & 3.29 & 2.21 & 5.06 & 7.12 \\
\hline 2009 & 5.61 & 5.00 & 1.98 & 4.02 & 6.98 \\
\hline 2010 & 3.89 & 2.77 & 1.93 & 2.85 & 5.10 \\
\hline 2011 & 4.09 & 3.29 & 1.86 & 2.99 & 4.96 \\
\hline 2012 & 3.73 & 2.80 & 1.81 & 2.83 & 4.92 \\
\hline 2013 & 2.91 & 1.92 & 1.91 & 2.00 & 3.95 \\
\hline & Statistical analysis: $\mathrm{H}=23.72 ; \mathrm{p}=0.0002 *$ & \\
\hline
\end{tabular}


child is $2 \%$, while when it affects girl the risk rises to $5 \%$. In case where one of the parents have the deformity the risk is as high as $25 \%$. Among the Polynesian population, the frequency of clubfoot inheritance stays on high levels of $54 \%$ [38-40]. Average hospitalization time of patients with CTAV in Children's Orthopedic Department of Medical University of Lublin in 2008 lasted around 5.56 days, in 2009 - 5.61 days, from 2010 the average dropped to 3.89 days, in year 2011 - 4.09 days, 2012 - 3.73 days while in 2013 the average hospitalization time decreased to 2.91 days. Conducted study shows that hospitalization time differences in the examined years were statistically significant $(\mathrm{p}=0.0002)$. V. Pavone [4] analyzed 82 clubfoot patients in the Orthopedic Clinic of Catania University, $68.29 \%$ of which were boys, while $31.71 \%$ were girls. In the researched group almost half of the patients $(49.68 \%)$ were less than one year old, while $21.29 \%$ were $1-3$ years old.

\section{RESULTS}

1. Congenital talipes equinovarus affects males more frequently than females.

2. Study shows that the average hospitalization time of clubfoot patients is systematically decreasing.

3. The authors' analysis shows that more patients are being admitted to Children's Orthopedic Department of Medical University of Lublin while the number of patients with clubfoot remains on the same level.

\section{REFERENCES}

1. Matuszewski Ł, Okoński M, Gil L, Ostrowski J, Okoński P, Korzyści w leczeniu stopy końsko szpotawej u dzieci przy pomocy metody Ponsetiego - lepsza efektywność przy mniejszej inwazyjności, Zdr Publ. 2013;123(1):53-6.

2. Ostrowski J, Karski T, Matuszewski Ł. The role of the modified skin incision, the range of tendon lengthening and capsulotomy for the results of operative treatment of the congenital clubfoot. PJOES. 2006;15(6B):2968.

3. Cummings RJ, Davidson RS, Armstrong PF, Lehman WB. Congenital clubfoot. Instr Course Lect. 2002;51:385-400.

4. Pavone V, Testa G, Costarella L, et al. Congenital idiopathic talipesequinovarus: an evaluation in infants treated by the Ponseti method. Eur Rev Med Pharm Sci. 2013;17:2675-9.

5. Porecha MM, Parmar DS, Chavda HR. Mid-term results of Ponseti method for the treatment of congenital idiopathic clubfoot (a study of 67 clubfeet with mean five year follow-up). J Orthop Surg Res. 2011;6:3.

6. Matthew B. Dobbs MD Update on Clubfoot: Etiology and Treatment. Clin Orthop Relat Res. 2009;467:1146-53.

7. Dimeglio A, Bensahel H, Souchet P, Mazeau P. Classification of clubfoot. J Pediatr Orthop B. 1995;4:129-36.

8. Kler J, Tomaszewski R, Wawrzyczek J, Bober K. Treatment methods of congenital talipes equinovarus - three case reports. J Pediatr Neonatol. 2005;2(1):18-21.

9. Miedzybrodzka Z. Congenital talipes equinovarus (clubfoot): a disorder of the food but not the hand. J Anat. 2003;202:37-42.

10. Sommer A, Blanton SH, Weymouth K, et al. Smoking, the xenobiotic pathway, and clubfoot. Birth Defects Res A Clin Mol Teratol. 2011;91(1):20-8.

11. Funk JF, Lebek S, Seidl T, Placzek R. Comparison of treatment results of idiopathic and non-idiopathic congenital clubfoot: prospective evaluation of the Ponseti therapy. Orthopade. 2012;41(12):977-83.

12. Palma M, Cook T, Segura J, et al. Barriers to the Ponseti method in Peru: a two-year follow-up. Iowa Orthop J. 2013;33:172-7.

13. Rijal R, Shrestha BP, Singh GK, et al. Comparison of Ponseti and Kite's method of treatment for idiopathic clubfoot. Indian J Orthop. 2010;44(2):202-7.

14. Gray K, Gibbons P. Clubfoot-advances in diagnosis and management. Aust Fam Physician. 2012;41(5):299-301.
15. Bridgens J, Kiely N. Current management of clubfoot (congenital talipesequinovarus) BMJ. 2010;340-55.

16. Morcuende JA. Congenital idiopathic clubfoot: prevention of late deformity and disability by conservative treatment with the Ponseti technique. Pediatr Ann. 2006;35(2):128-30, 132-6.

17. Desai L, Oprescu F, DiMeo A, Morcuende JA. Bracing in the treatment of children with clubfoot: past, present, and future. Iowa Orthop J. 2010;30:15-23.

18. Harmer L, Rhatigan J. Clubfoot care in low-income and middle-income countries: from clinical innovation to a public health program. World $\mathrm{J}$ Surg. 2014;38(4):839-48.

19. Pirani S, Naddumba E, Mathias R, et al. Towards effective Ponseti clubfoot care: The Uganda sustainable clubfoot care project. Clin Orthop Relat Res PMC. 2009;467:1154-63.

20. Chapman C, Stott S, Viola Port RV, et al. Segregation analysis of idiopathic talipes equinovarus in Texan population. Am J Med Genet. 1998;79:97102.

21. Brougham DI, Nicol RO. Use of the Cincinnati incision in congenital talipes equinovarus. J Pediatr Orthop. 1988;8:696-8.

22. Halanski MA, Maples D, Davison J. et al. Separating the Chicken from the Egg: An Attempt to Discern Between Clubfoot Recurrences and Incomplete Corrections. The Iowa Orthop J. 2010;V30:29-34.

23. Kruse LM, Dobbs MB, Gurnett CA. Polygenic threshold model with sex dimorphism in clubfoot inheritance: the Carter effect. J Bone Joint Surg Am. 2008;90:2688-94.

24. Werler MM, Yazdy MM, Mitchell AA, et al. Descriptive epidemiology of idiopathic clubfoot. Am J Med Genet A. 2013;161A(7):1569-78.

25. Ostrowski J. Odległe badania nad zmiennością morfologiczną i czynnościową stóp u osób operowanych w okresie niemowlęcym i wczesnodziecięcym z powodu deformacji końsko-szpotawych. Rozprawa doktorska. Lublin: Uniwersytet Medyczny w Lublinie; 2002.

26. Bakalis S, Sairam S, Homfray T, et al. Outcome of antenatally diagnosed talipes equinovarus in an unselected obstetric population. Ultrasound $\mathrm{Ob}$ stet Gynecol. 2002;20(3):226-9.

27. Gibbons PJ, Gray K. Update on clubfoot. J Paediatr Child Health. 2013;49(9):E434-7.

28. Dietz FR. The genetics of idiopathic clubfoot. Clin Orthop Rel Res. 2002;401:39-48.

29. Engell V, Nielsen J, Damborg F, et al. Heritability of clubfoot: a twin study. J Child Orthop. 2014;8(1):37-41.

30. Lochmiller C, Johnston D, Scott A, et al. Genetic epidemiology study of idiopathic talipesequinovarus. Am J Med Genet. 1998;79:90-6.

31. Honein MA, Paulozzi LJ, Moore CA. Family history, maternal smoking, and clubfoot: an indication of a gene-environment interaction. Am J Epidemiol. 2000;152:658-65.

32. Hecht JT, Ester A, Scott A, Wise CA, et al. NAT2 variation and idiopathic talipesequinovarus (clubfoot). Am J Med Genet A. 2007;143:2285-91.

33. Dickinson KC, Meyer RE, Kotch J. Maternal smoking and the risk for clubfoot in infants. Birth Defects Res A Clin Mol Teratol. 2008;82(2):8691.

34. Hackshaw A, Rodeck C, Boniface S. Maternal smoking in pregnancy and birth defects: a systematic review based on 173687 malformed cases and 11.7 million controls. Hum Reprod Update. 2011;17(5):589-604.

35. Ponseti IV. Wrodzona stopa końsko-szpotawa: leczenie metodą Ponsetiego. Seattle: Global-Help Organization; 2007. p. 1-11.

36. Kołecka E, Niedzielski K, Cukras Z, Piotrowicz M. Wrodzona stopa końsko-szpotawa - występowanie rodzinne. Chir Nardz Ruchu Ortop Pol. 2011;76(5):252-5.

37. Chapman C, Scott N, Port R. Genetics of clubfoot In Maori and Pacific people. J Med Genet. 2000;37:680-3.

38. Barker S, Chesney D, Miedzybrodzka Z, Maffuli N. Genetics and epidemiology of idiopatic congenital talipes equinovarus. J Pediatr Orthop. 2003;(23):265-72.

39. GurnettCh, Alae F, Kruse L. Asymmetric Lower-Limb Malformations in Individuals with Homeobox PITX1 Gene Mutation. Am J Hum Gen. 2008;(7):616-22.

40. Yang H, Chung C, Nemachek W. A genetic analysis of clubfoot in Hawaii. Genet. Epidemiol. 1987;(4):299-306.

\section{Corresponding author}

Patrycja Misztal-Okońska

Department of Expert Medical Assistance with Emergency Medicine Unit,

Medical University of Lublin

4/6 Staszica Str., 20-081 Lublin

E-mail: patrycja.okonska@umlub.pl 